\title{
Antibacterial interactions, anti-inflammatory and cytotoxic effects of four medicinal plant species
}

\author{
Refilwe G. Kudumela', Lyndy J. McGaw² and Peter Masoko ${ }^{1 *}$
}

\begin{abstract}
Background: The constant emergence of antibiotic resistant species and the adverse side effects of synthetic drugs are threatening the efficacy of the drugs that are currently in use. This study was aimed at investigating the possible antibacterial interactions, anti-inflammatory and cytotoxic effects of selected medicinal plants based on their traditional usage.

Methods: The acetone extracts of four plant species were assessed independently and in combination for antibacterial activity using microdilution assay and the sum of the fractional inhibitory concentration (FIC) was calculated. The ability of Dombeya rotundifolia and Schkuhria pinnata extracts to inhibit the production of reactive oxygen species (ROS) in LPS induced RAW 264.7 macrophage cells was evaluated using Dichlorodihydro-fluorescein diacetate $\left(\mathrm{H}_{2} \mathrm{DCF}-\mathrm{DA}\right)$ assay to determine anti-inflammatory potential and the toxicity on African green monkey kidney (Vero) cells was evaluated using 3-(4,5-dimethylthiazol-2-yl)-2,5-diphenyl tetrazolium bromide (MTT) assay.

Results: The antibacterial efficacies of the different combinations of Schkuhria pinnata (A), Commelina africana (B), Dombeya rotundifolia (C) and Elephantorrhiza elephantina (D) plants varied from combination to combination. Synergistic effects were only exhibited against $P$. aeruginosa, while the antagonistic effects were only observed against $E$. coli. Both S. pinnata and D. rotundifolia demonstrated anti-inflammatory potential by inhibiting the production of ROS in a dose dependant manner. The cytotoxicity of the plants ( $L C_{50}$ values) ranged from $<25.0$ to $466.1 \mu \mathrm{g} / \mathrm{mL}$. S pinnata extract was the most toxic with the lowest $\mathrm{LC}_{50}$ value of $<25.0 \mu \mathrm{g} / \mathrm{mL}$.

Conclusions: The synergistic interaction observed indicates that combinational therapy may improve biological activity. This report highlights the anti-inflammatory potential of S. pinnata and D. rotundifolia; which could be exploited in the search for anti-inflammatory agents. However, the cytotoxicity of $S$. pinnata highlights the importance of using this plant with caution.
\end{abstract}

\section{Background}

The extensive use and over reliance on antibiotics has caused the bacteria to develop resistant genes against the available antibiotics [1]. Some antibiotics have been associated with undesirable side effects, such as; nausea, depression of bone marrow, thrombocytopenic and agranulocytosis [2], therefore medicinal plants are researched as possible new sources of antimicrobial

\footnotetext{
* Correspondence: Peter.Masoko@ul.ac.za

${ }^{1}$ Department of Biochemistry, Microbiology and Biotechnology, Faculty of Science and Agriculture, University of Limpopo, Turfloop Campus, Private Bag X1106, Sovenga, Limpopo 0727, South Africa

Full list of author information is available at the end of the article
}

agents with possibly novel mechanisms of action and fewer side effects since they have therapeutic relevance in folklore [3-7]. These medicinal plants are used in the form of herbal remedies which are prepared from one plant or a combination of different plant species [8]. Herbal mixtures containing a combination of different plant species have been reported to have better biological activities than isolated active compounds and herbal mixtures prepared from one plant species [8-10]. Therefore, these could be used to overcome the challenge of antimicrobial resistance [11].

The use of traditional medicine systems to treat various ailments has been in existence for years and 
continues to provide the human population with new medicines [12]. A single plant can be used for treatment of more than one type of disease and as a result have multiple medicinal properties. This justifies why it is important to screen for more than one biological activity when screening plants for biological activity. This approach explores and provides information on the overall medicinal properties of specific medicinal plants [11]. The current steroidal and non-steroidal anti-inflammatory drugs present adverse side effects, thus, exploring plants as an alternative has been increasing significantly [13].

Medicinal plants are assumed to be safe based on their long history of use in the treatment and management of diseases [14]. However, the use of these plants may be associated with irritation of the gastrointestinal tract, destruction of red blood cells, and damage of the heart and kidney [15]. Therefore, this necessitates the need for cytotoxicity evaluation of medicinal plants used in ethnopharmacology. The present study investigated the antibacterial interactions, anti-inflammatory and cytotoxic effects of the four selected plants. This was motivated by the results obtained in our previous work on phytochemical screening, antioxidant and antibacterial effects of the same plants [16]. The plants selected for this study include; Commelina africana L. var. africana (Commelinaceae) which is used traditionally for the treatment of venereal diseases [17]; Dombeya rotundifolia (Hochst.) Planch. var. (Sterculiaceae) used traditionally to treat diarrhoea [18]; Elephantorrhiza elephantina (Burch.) Skeels (Leguminosae) used for treatment of pneumonia and tick-borne diseases in cows [19] and Schkuhria pinnata (Lam.) Kuntze ex Thell (Asteraceae) which is used for treatment of stomach ache [20].

\section{Methods}

\section{Chemicals}

Acetone (Sigma Aldrich, SA), Ampicillin (Sigma Aldrich, SA), nutrient broth (Oxiod), Curcumin (Adcock-Ingram), Dichloro-dihydro-fluorescein diacetate $\left(\mathrm{H}_{2} \mathrm{DCF}-\mathrm{DA}\right)$ (ThermoFisher Scientific), Lipopolysaccharide (LPS) (ThermoFisher Scientific), RPMI-1640 medium (Whitehead Scientific), Phosphate Buffered Saline (PBS) (White Scientific), foetal bovine serum (FBS) (Hyclone, Thermo Scientific), Minimum Essential Medium (MEM, Whitehead Scientific) gentamicin (Virbac) 3-(4, 5-dimethylthiazol2-yl)-2, 5-diphenyltetrazolium bromide (MTT) (Sigma Aldrich, SA), foetal calf serum (Highveld Biological).

\section{Plant collection and preparations}

The leaves of (Commelina africana $\mathrm{L}$. var. africana (UNIN 12295), Dombeya rotundifolia (Hochst.) Planch. var. rotundifolia (UNIN 12296), Elephantorrhiza elephantina (Burch.) Skeels (UNIN 12297) and the whole plant excluding the roots of Schkuhria pinnata (Lam.)
Kuntze ex Thell (UNIN 12298) were collected in April 2015 at University of Limpopo, South Africa. The specimens were deposited at the Larry Leach Herbarium (UNIN) for authentication. Plant collection was based on ethnopharmacological information provided by traditional healers in Limpopo Province. The plants were dried at room temperature, protected from light and later ground to fine powder using a blender (Waring Laboratory Blender LB20ES). The plant materials (10 g) were extracted using acetone $(100 \mathrm{~mL})$ (Sigma-Aldrich, S.A) and the supernatants of each plant material were filtered through Whatman No.1 filter paper into pre-weighed vials and the filtrates were dried under a stream of air. The dried filtrates yielded $0.3 \mathrm{~g}, 0.7 \mathrm{~g}$, $1.08 \mathrm{~g}$ and $0.5 \mathrm{~g}$ for C. africana, D. rotundifolia, E. elephantina and S. pinnata respectively.

\section{Microorganisms used in this study}

Two Gram-positive bacteria (Staphylococcus aureus ATCC 29213 and Enterococcus faecalis ATCC 29212) and 2 Gram-negative bacteria (Escherichia coli ATCC 28922 and Pseudomonas aeruginosa ATCC 27853) were used. These are major causes of nosocomial infections in hospitals [21] and are mainly the strains recommended for use by the National Committee for Clinical Laboratory Standards [22]. The bacterial species were maintained on nutrient agar at $4{ }^{\circ} \mathrm{C}$. The cells were inoculated and incubated at $37{ }^{\circ} \mathrm{C}$ in nutrient broth for $12 \mathrm{~h}$ prior to screening tests.

\section{Antibacterial interaction activity}

The antibacterial activity interactions of the four selected plants were investigated by the determination of the minimum inhibitory concentration (MIC) of each plant independently and in combination using the micro-broth dilution assay described by Eloff [23]. Stock solutions $(10 \mathrm{mg} / \mathrm{mL})$ of acetone extracts of each plant were prepared by re-dissolving the extracts in acetone. For $1: 1$ test combinations, $50 \mu \mathrm{L}$ of each of the two extracts were mixed to make up a volume of $100 \mu \mathrm{L}$ in the first wells of a 96-well microtitre plate. Each extract contributed $33.3 \mu \mathrm{L}$ and $25 \mu \mathrm{L}$ for the 1:1:1 and 1:1:1:1 combinations respectively, to make up $100 \mu \mathrm{L}$ in the first wells of a 96-well microtitre plate [8]. Two-fold serial dilutions of these extracts and ampicillin (positive control) $(2.5 \mathrm{mg} / \mathrm{mL}$ to $0.02 \mathrm{mg} / \mathrm{mL}$ ) were prepared in 96-well microtitre plates. The effects of the extracts were tested against $100 \mu \mathrm{L}$ of each pathogen at the following densities of bacterial cultures: S. aureus, $2.6 \times 10^{12}$ colony-forming units $(\mathrm{CFU} / \mathrm{mL}) ;$ E. faecalis, $1.5 \mathrm{X}$ $10^{10} \mathrm{CFU} / \mathrm{mL}$; P. aeruginosa, $5.2 \times 10^{13} \mathrm{CFU} / \mathrm{mL}$; E. coli, $3.0 \times 10^{11} \mathrm{CFU} / \mathrm{mL}$. The microtitre plates were incubated at $37{ }^{\circ} \mathrm{C}$ overnight. Thereafter, $40 \mu \mathrm{L}$ of $0.2 \mathrm{mg} /$ $\mathrm{mL}$ iodonitrotetrazolium chloride (Sigma-Aldrich) was 
added to each well and the plates were re-incubated for a further $30 \mathrm{~min}$ at $37{ }^{\circ} \mathrm{C}$ for $S$. aureus and $P$. aeruginosa, $1.5 \mathrm{~h}$ for E. coli, and $24 \mathrm{~h}$ for E. faecalis. The formation of a red-pink color signified microbial growth. All samples were assayed in triplicates and acetone was used as a negative control. The synergistic or antagonistic interactions between the plants were investigated by determining the Fractional inhibitory concentrations (FIC). These were calculated for 1:1 combinations of the plants with the equation below, where (i) and (ii) represented the different 1:1 plant combinations [24]. The FIC index was expressed as the sum of FIC (i) and FIC (ii) and this was used to classify the interaction as either synergistic $(\leq 0.50)$, additive $(0.50-1.00)$, indifferent (> $1.00-4.00)$ or antagonistic $(>4.00)[25]$.

$$
\begin{aligned}
& \text { FIC(i) } \frac{\text { MIC of (a)in combination with (b) }}{\text { MIC of (a)independently }} \\
& \text { FIC(ii) } \frac{\text { MIC of (b)in combination with (a) }}{\text { MIC of (b)independently }}
\end{aligned}
$$

\section{Anti-inflammatory activity assay using Dichloro-dihydro- fluorescein diacetate $\mathrm{H}_{2}$ DCF-DA assay}

Based on the reported high antioxidant and antibacterial activities of $D$. rotundifolia and S. pinnata respectively [16] the anti-inflammatory activity assay of the two plants were investigated using the $\mathrm{H}_{2}$ DCF-DA assay as described by Sekhar et al., [26] with slight modifications. This assay uses stimulants such as lipopolysaccharide (LPS) to induce oxidative stress and Dichloro-dihydro-fluorescein diacetate $\left(\mathrm{H}_{2} \mathrm{DCF}-\mathrm{DA}\right)$ to detect the presence of reactive oxygen species.. In the presence of reactive oxygen species $\mathrm{H}_{2}$ DCF-DA is oxidized to fluorescent 2, 7-dichlorofluorescein (DCF). Two hundred microliters of cells (RAW 264.7 macrophages) obtained from the American Type Culture Collection (ATCC) in RPMI-1640 was seeded in a 96-well plate. The cells were incubated at $37{ }^{\circ} \mathrm{C}, 5 \% \mathrm{CO}_{2}$ overnight to attain confluency. The medium was removed and the cells were washed with Phosphate Buffered Saline (PBS). Cells were exposed to $100 \mu \mathrm{L}$ of acetone extracts $(8 \mathrm{mg} / \mathrm{mL}, 0.64 \mathrm{mg} / \mathrm{mL}$, and $0.32 \mathrm{mg} / \mathrm{mL}$ ) of $D$. rotundifolia and S. pinnata and $20 \mu \mathrm{L}$ of LPS for $24 \mathrm{~h}$. Following incubation, the medium was aspirated and fresh medium without Foetal Bovine Serum (FBS) was added and the cells were stained with $100 \mu \mathrm{L}$ of $20 \mu \mathrm{M}$ of $\mathrm{H}_{2}$ DCF-DA and incubated for $30 \mathrm{~min}$ in the dark. The fluorescence was measured at an excitation wavelength of $480 \mathrm{~nm}$. Curcumin $(50 \mu \mathrm{M})$ and untreated cells were used as positive and negative controls respectively.

\section{Cytotoxicity assay}

The toxic effects of the selected plants on African green monkey kidney (Vero) cells obtained from the culture collection of the Department of Veterinary Tropical Diseases (University of Pretoria) was determined by the 3-(4, 5-dimethylthiazol-2-yl)-2, 5-diphenyltetrazolium bromide (MTT) assay [27]. The cells were maintained in Minimum Essential Medium (MEM, Whitehead Scientific) supplemented with $0.1 \%$ gentamicin (Virbac) and $5 \%$ foetal calf serum (Highveld Biological). The cell suspension $\left(5 \times 10^{4}\right.$ cells $\left./ \mathrm{mL}\right)$ was seeded in a sterile 96-well microtitre plate and incubated for $24 \mathrm{~h}$ at $37{ }^{\circ} \mathrm{C}$ in $5 \% \mathrm{CO}_{2}$ for the cells to attach. The MEM was aspirated and the cells were washed with $150 \mu \mathrm{L}$ phosphate buffered saline (PBS, Whitehead Scientific). The cells were treated with different concentrations of the extracts $(1-0.025 \mathrm{mg} / \mathrm{mL})$ prepared in MEM. The microtitre plates were incubated for $48 \mathrm{~h}$ with the extracts in the same conditions as described earlier. Untreated cells were included as a negative control. After treatment, the treatment medium was aspired and replaced with $200 \mu \mathrm{L}$ of fresh MEM and then $30 \mu \mathrm{L}$ of MTT $(5 \mathrm{mg} /$ $\mathrm{mL}$ ) in PBS (Sigma) and the plates were incubated further for $4 \mathrm{~h}$ at $37^{\circ} \mathrm{C}$. The medium was removed and replaced with $50 \mu \mathrm{L}$ of DMSO to dissolve the MTT formazan crystals. The absorbance was measured in a microplate reader (BioTek Synergy) at $570 \mathrm{~nm}$. Cytotoxicity was expressed as the concentration of test sample resulting in a $50 \%$ reduction of absorbance compared to untreated cells $\left(\mathrm{LC}_{50}\right.$ values). All the analysis was made in quadruplicate. The selectivity index (SI) was expressed as $\mathrm{LC}_{50} / \mathrm{MIC}$ value.

\section{Statistical analysis}

Each experiment was performed in triplicates and the results were expressed as mean values. Linear regression analysis was used to calculate $\mathrm{LC}_{50}$ values. Microsoft Excel $^{\circ}$ was used to enter and capture data. Various graphs and tables were extracted from this data. Data was then exported to SPSS for further analysis. The MIC for each microorganism was analyzed using one-way analysis of variance (ANOVA). $P$ value $<0.05$ was considered as significant. SPSS 25.0 was employed for statistical analysis.

\section{Results}

\section{Antibacterial interaction activity assay}

When the plants were combined in a 1:1:1 combination potent activities were observed when $S$. pinnata was combined with $C$. africana and D. rotundifolia (combination $\mathrm{A}+\mathrm{B}+\mathrm{C})$ against $E$. coli $(0.09 \pm 0.04 \mathrm{mg} / \mathrm{mL})$ and $P$. aeruginosa $(0.06 \pm 0.02 \mathrm{mg} / \mathrm{mL})$. Meanwhile, the combination with $D$. rotundifolia, $S$. pinnata, and E. elephantina $(\mathrm{C}+\mathrm{A}+\mathrm{D})$ exhibited potent activities against $P$. aeruginosa $(0.07 \pm 0.04 \mathrm{mg} / \mathrm{mL})$ only (Table 1$)$. When all 
Table 1 Antibacterial interaction effects with standard deviation of the acetone extracts of the different combinations of the selected plants against selected bacterial species

\begin{tabular}{|c|c|c|c|c|}
\hline \multirow[t]{2}{*}{ Combinations } & \multicolumn{4}{|c|}{ Minimum Inhibitory Concentration (mg/ml) } \\
\hline & Escherichia coli & Pseudomonas aeruginosa & Enterococcus faecalis & Staphylococcus aureus \\
\hline $\bar{A}$ & $0.84 \pm 0.21$ & $0.27 \pm 0.05$ & $1.67 \pm 0.83$ & $1.67 \pm 0.83$ \\
\hline$A+B$ & $0.16 \pm 0.00$ & $0.04 \pm 0.00$ & $0.63 \pm 0.00$ & $0.53 \pm 0.10$ \\
\hline$A+B+C$ & $0.09 \pm 0.04$ & $0.06 \pm 0.02$ & $0.63 \pm 0.00$ & $0.32 \pm 0.00$ \\
\hline$A+B+C+D$ & $0.13 \pm 0.03$ & $0.07 \pm 0.04$ & $0.63 \pm 0.00$ & $0.27 \pm 0.53$ \\
\hline B & $0.03 \pm 0.01$ & $0.53 \pm 0.10$ & $1.67 \pm 0.83$ & $0.84 \pm 0.00$ \\
\hline$B+C$ & $0.13 \pm 0.03$ & $0.67 \pm 0.59$ & $0.63 \pm 0.00$ & $0.32 \pm 0.00$ \\
\hline$B+C+D$ & $0.13 \pm 0.03$ & $0.76 \pm 0.59$ & $0.63 \pm 0.00$ & $0.21 \pm 0,05$ \\
\hline C & $0.52 \pm 0.36$ & $0.42 \pm 0.10$ & $1.25 \pm 0.00$ & $0.63 \pm 0.00$ \\
\hline$C+A$ & $0.73 \pm 0.27$ & $0.04 \pm 0.00$ & $1.25 \pm 0.00$ & $0.84 \pm 0.21$ \\
\hline$C+A+D$ & $0.52 \pm 0.36$ & $0.07 \pm 0.04$ & $1.04 \pm 0.21$ & $0.84 \pm 0.21$ \\
\hline D & $1.04 \pm 0.21$ & $0.42 \pm 0.10$ & $1.67 \pm 0.83$ & $0.84 \pm 0.21$ \\
\hline$D+C$ & $0.63 \pm 0.00$ & $0.04 \pm 0.00$ & $1.67 \pm 0.83$ & $0.84 \pm 0.21$ \\
\hline$D+A+B$ & $0.16 \pm 0.00$ & $0.67 \pm 0.59$ & $0.63 \pm 0.00$ & $0.27 \pm 0.5$ \\
\hline Ampicillin & 0.03 & 0.02 & 0.03 & 0.08 \\
\hline
\end{tabular}

Keywords

$\mathrm{A}=$ Schkuhria pinnata $\mathrm{B}=$ Commelina africanaC $=$ Dombeya rotundifoliaD $=$ Elephantorrhiza elephantina

the selected plants were combined (combination A + B $+\mathrm{C}+\mathrm{D})$ the efficacy against all the tested bacteria except for $E$. coli was enhanced with average MIC values lower than the MIC values of the plants independently. Ampicillin was used as positive control and its MIC values ranged from 0.02 to $0.08 \mathrm{mg} / \mathrm{mL}$. Using ANOVA test (one way ANOVA), the mean difference between the MIC values of some of the acetone extracts combination $(\mathrm{A}+\mathrm{B} ; \mathrm{A}+\mathrm{B}+\mathrm{C} ; \mathrm{A}+\mathrm{B}+\mathrm{C}+\mathrm{D}$ and $\mathrm{C}+\mathrm{A}$ against all tested pathogens was statistically significant $(p<0.05)$.

The Fractional Inhibitory Concentration (FIC) values were calculated as outlined above for the 1:1 combinations to establish any synergistic or antagonistic interactions. Synergistic effects were only exhibited against $P$. aeruginosa with $0.22,0.24$, and $0.19 \mathrm{FIC}$ index values for the $\mathrm{A}+\mathrm{B}, \mathrm{C}+\mathrm{A}$ and $\mathrm{C}+\mathrm{D}$ combinations, respectively. Meanwhile, the antagonistic effects were only observed against $E$. coli with 5.52 and 4.58 FIC index values for combinations $\mathrm{A}+\mathrm{B}$ and $\mathrm{B}+\mathrm{C}$ respectively (Table 2 ).

\section{Anti-inflammatory activity}

The plant extracts inhibited ROS generation in a dose dependant manner. The inhibition was higher in $D$. rotundifolia than in $S$. pinnata (Fig. 1). Curcumin $(50 \mu \mathrm{M})$ was used as a positive control and all the plants had better anti-inflammatory potential than curcumin at the highest concentration tested. Potent activities were observed in D. rotundifolia even at the lowest concentration tested.

\section{Cytotoxicity assay}

The cytotoxicity of the acetone extracts of the selected plants ranged from $<25$ to $466.1 \mu \mathrm{g} / \mathrm{mL}$. The American National Cancer Institute (NCI) described an $\mathrm{LC}_{50}<$ $30 \mu \mathrm{g} / \mathrm{mL}$ for plant extracts as a cut off point for cytotoxicity after $72 \mathrm{~h}$ of exposure [28]. Therefore, S. pinnata extract was highly toxic to the Vero cells with the lowest $\mathrm{LC}_{50}(<25 \mu \mathrm{g} / \mathrm{mL})$ that is outside the cut-off point (Table 3).

\section{Discussion}

Most traditional healers in South Africa often combine different plants in herbal mixtures. This method has been proposed to be a better way of approaching antimicrobial resistance problem [11]. Plants used in this study, have been reported to have antibacterial activities independently against the tested bacteria [16], hence we here evaluated the possible antibacterial interactions between the plants to see if such combination will potential their antimicrobial activity. To achieve this, the

Table 2 Fractional inhibitory concentration indexes of the 1:1 combinations of the selected plants

\begin{tabular}{lllll}
\hline Microorganisms & $\mathrm{A}+\mathrm{B}$ & $\mathrm{B}+\mathrm{C}$ & $\mathrm{C}+\mathrm{A}$ & $\mathrm{C}+\mathrm{D}$ \\
\hline Escherichia coli & 5.52 & 4.58 & 2.27 & 1.82 \\
Pseudomonas aeruginosa & 0.22 & 2.86 & 0.24 & 0.19 \\
Enterococcus faecalis & 0.75 & 0.88 & 1.75 & 2.34 \\
Staphylococcus aureus & 0.95 & 0.89 & 1.84 & 2.33 \\
\hline
\end{tabular}

Keywords

$\mathrm{A}=$ Schkuhria pinnata $\mathrm{B}=$ Commelina africanaC $=$ Dombeya

rotundifoliaD = Elephantorrhiza elephantina 


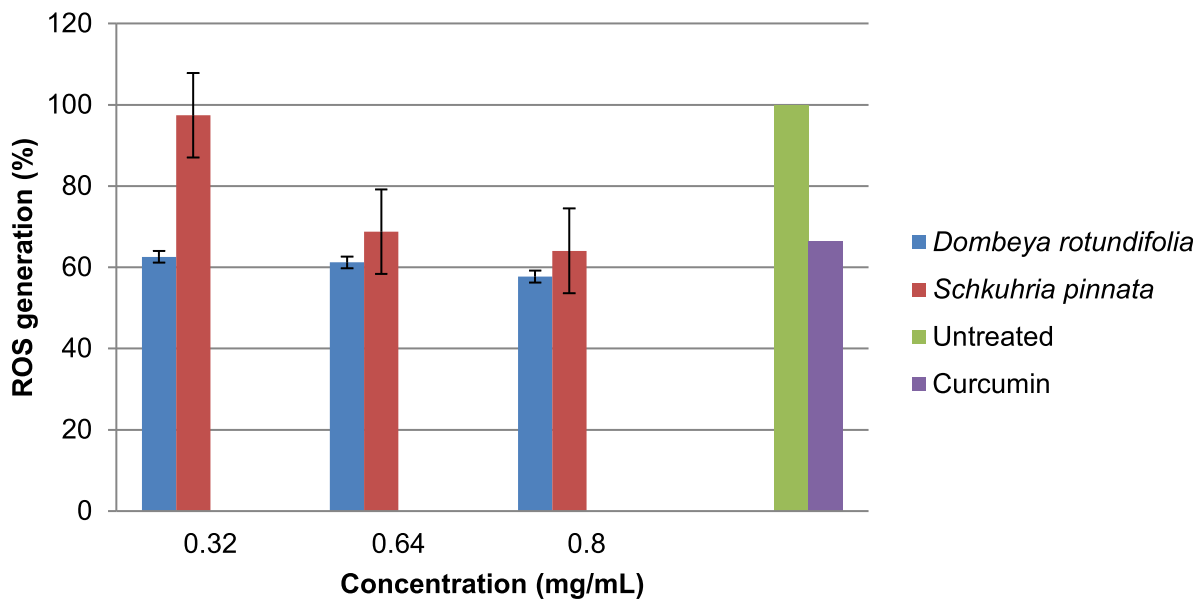

Fig. 1 The effect of two of the selected plants on ROS generation inhibition activity in LPS induced RAW 264.7 macrophage cells

Minimum Inhibitory Concentration (MIC) values of acetone extracts of the selected plants individually and in combination were determined (Table 1). As suggested by Ríos and Recio [29] this study highlights only the MIC values of less or equal to $0.1 \mathrm{mg} / \mathrm{mL}$ as these are said to be noteworthy.

Overall the Gram-negative bacteria were more sensitive to the combinations than the Gram-positive bacteria. The difference in sensitivity for these bacteria may be attributed to the difference in membrane morphology [30]. This suggests that the problem of antimicrobial resistance of the Gram-negative strains may be addressed with combinational therapy of these plants. In most cases it is assumed that when two plants are combined synergism is likely to occur [31]. The plants contained in the combinations in this study are used for treatment of various infections and they have been screened for antimicrobial properties individually [16, 32-35]. Mpofu [31] also reported on the synergistic interactions of the 1:1 combinations of Elephantorrhiza elephantina and Pentanisia prunelloides aqueous extracts against $E$. coli and E. faecalis. As such, one could advice on the combination of these plants since combination of plant extracts often offer a wide range of biological activities [36].

There are substantial numbers of reports linking ROS production to inflammation and related diseases [26,
37]. As such, the effects of S. pinnata and D. rotundifolia acetone extracts on the inhibition of ROS production were investigated in LPS induced RAW 264.7 macrophage cells. This plant was reported to have high free radical scavenging and ferric reducing antioxidant properties [16]. Therefore, the observed anti-inflammatory effect may be attributed to these antioxidant properties. Nevertheless, S. pinnata also exhibited ROS inhibition activity at higher concentrations. Therefore, the anti-inflammatory efficacy should be evaluated in vivo before the plant is recommended for any use. Reid et al. [33] also reported on the high inflammatory activity of the ethanol and dichloromethane leaf and bark extracts of $D$. rotundifolia. Meanwhile, Luseba et al. [38] reported that DCM extracts of $S$. pinnata had high inhibitory activity against cyclooxgenase- 1 enzyme (COX-1). More often farmers use the same plants to treat different degrees of inflammation and stages of infections [38]. This statement was supported by the potent antibacterial and anti-inflammatory activities of both $S$. pinnata and $D$. rotundifolia.

Many of the plants used in ethnopharmacology to treat various ailments are used with no knowledge of their toxic effect [15]. As such, the toxic effects of the selected plants were evaluated on African green monkey (Vero) cells using MTT assay. This assay is based on the

Table 3 Cytotoxicity, Minimum Inhibitory Concentrations (MIC), and selectivity index (SI) of the acetone extracts of the selected plants

\begin{tabular}{|c|c|c|c|c|c|c|c|c|c|}
\hline \multirow[t]{2}{*}{ Plant species } & \multirow{2}{*}{$\begin{array}{l}\mathrm{LC}_{50} \\
(\mu \mathrm{g} / \mathrm{mL})\end{array}$} & \multicolumn{4}{|c|}{ MIC values ( $\mu \mathrm{g} / \mathrm{mL})$} & \multicolumn{4}{|c|}{ Selectivity index (SI) } \\
\hline & & E. coli & P. aeruginosa & E. faecalis & S. aureus & E. coli & P. aeruginosa & E. faecalis & S. aureus \\
\hline Schkuhria pinnata & $<25.0$ & 320 & 640 & 1250 & 1250 & 0.08 & 0.04 & 0.02 & 0.02 \\
\hline Dombeya rotundifolia & 466.1 & 320 & 1250 & 1250 & 1250 & 1.46 & 0.37 & 0.37 & 0.37 \\
\hline Elephantorrhiza elephantina & 416.4 & 640 & 2500 & 2500 & 2500 & 0.17 & 0.17 & 0.17 & 0.17 \\
\hline Commelina africana & 441.1 & 20 & 2500 & 2500 & 2500 & 22.06 & 0.18 & 0.18 & 0.18 \\
\hline
\end{tabular}


conversion of MTT to an insoluble purple formazan by the mitochondrial succinate dehydrogenase of viable cells [39]. The concentrations of the extracts which resulted in $50 \%$ reduction of absorbance compared to untreated cells $\left(\mathrm{LC}_{50}\right)$ are presented in Table 3. Deutschländer et al. [40] also reported the toxicity of the acetone and ethanol extracts of S. pinnata on 3 T3-L1 preadipocytes and Chang liver cells. However, McGaw et al. [41] reported that plants containing toxic compounds may have useful biological activities, since toxicity at low doses can be associated with pharmacological activity. Nevertheless, the rest of the plants were less toxic with high $\mathrm{LC}_{50}$ values.

Selectivity index was used to relate cytotoxicity and antibacterial activities of plant extracts. These values ranged from 0.02 to 22.06 (Table 3). The plant extracts had low selectivity with an exception of $C$. africana (22.06). The efficacy of biological activity is considered not to be due to toxicity if the selectivity index is $\geq 10$ [42]. Therefore the observed antibacterial activity of acetone leaf extracts of $C$. africana was not due to toxicity. Meanwhile, those of the other plants were probably due to toxicity because of their low selectivity index values. It should be noted that cytotoxicity observed in vitro is not always encountered in vivo. This is probably because when in the biological system, some toxic compounds have the ability to undergo metabolic transformations which leads to the formation of less toxic end products [43].

\section{Conclusions}

This study demonstrated that combinational therapy may be used to address antimicrobial resistance of Gram-negative strains. Furthermore, this report highlights the anti-inflammatory potential of $S$. pinnata and $D$. rotundifolia acetone extracts which could be exploited in the search for plant-based anti-inflammatory agents. However, the cytotoxicity of S. pinnata highlights the importance of using this plant with caution.

\section{Abbreviations}

COX: cyclooxygenases; DCFHD-A: dichlorofluorescein diacetate assay; FIC: fractional inhibitory concentration; iNOS: inducible nitric oxide synthase; MEM: Minimum Essential Medium; RNS: Reactive nitrogen species; ROS: Reactive oxygen species

\section{Acknowledgements}

The authors thanks Ms. Mangokoana for assistance with anti-inflammatory studies.

\section{Funding}

We would like to thank the NRF (Reference: IFR1203260814; SFH150709124813; Grant No: 81341 and University of Limpopo (Grant no: 624) for financial support.

\section{Availability of data and materials}

The datasets used and/or analyzed during the current study are available from the corresponding author on reasonable request.

\section{Conflict of interests}

The authors declare that there is no conflict of interests regarding the publication of this paper.

\section{Authors' contributions}

RGK, carried out the experiments, analysed the data and drafting of the manuscript. LMM: Toxicity studies and proof reading. PM, study design, data collection, analysis and interpretation of data and drafting of the manuscript. All authors read and approved the final manuscript.

Ethics approval and consent to participate

Not applicable.

\section{Consent for publication}

Not applicable.

\section{Publisher's Note}

Springer Nature remains neutral with regard to jurisdictional claims in published maps and institutional affiliations.

\section{Author details}

${ }^{1}$ Department of Biochemistry, Microbiology and Biotechnology, Faculty of Science and Agriculture, University of Limpopo, Turfloop Campus, Private Bag X1106, Sovenga, Limpopo 0727, South Africa. ${ }^{2}$ Department of Paraclinical Sciences, Phytomedicine Programme, Faculty of Veterinary Science, University of Pretoria, Private Bag X04, Onderstepoort 0110, South Africa.

Received: 31 January 2018 Accepted: 22 June 2018

Published online: 03 July 2018

\section{References}

1. Mundy L, Pendry B, Rahman M. Antimicrobial resistance and synergy in herbal medicine. J Herb Med. 2016;6:53-8.

2. Marchese A, Schito GC. Resistance patterns of lower respiratory tract pathogens in Europe. Int J Antimicrob Agents. 2000;16:25-9.

3. Machado TB, Pinto AV, Pinto MCFR, Leal ICR, Silva MG, Amaral ACF, Kuster RM, Netto-dosSantos KR. In vitro activity of Brazilian medicinal plants, naturally occurring naphthoquinones and their analogues, against methicillin-resistant Staphylococcus aureus. Int J Antimicrob Agents. 2003;21: 279-84.

4. Motsei ML, Lindsey KL, van Staden J, Jäger AK. Screening of traditionally used south African plants for antifungal activity against Candida albicans. J Ethnopharmacol. 2003;86:235-41.

5. Barbour EK, Al Sharif M, Sagherian VK, Habre AN, Talhouk RS, Talhouk SN. Screening of selected indigenous plants of Lebanon for antimicrobial activity. J Ethnopharmacol. 2004;93:1-7.

6. Parekh J, Chanda S. In vitro antibacterial activity of the crude methanol extract of Woodfordia fruticosa Kurz. Flower (Lythraceae). Braz J Microbiol. 2007b;38:204-7.

7. Ncube B, Finnie JF, van Staden J. In vitro antimicrobial synergism within plant extracts combinations from three south African medicinal bulbs. J Ethnopharmacol. 2012;139:81-9.

8. Chung PY, Navaratnam P, Chung LY. Synergistic antimicrobial activity between pentacyclic triterpenoids and antibiotics against Staphylococcus aureus strains. Ann Clin Microbiol Antimicrob. 2011;10:25-30.

9. Nahrstedt A, Butterweck V. Lessons learned from herbal medicinal products: the example of St. John's wort. J Nat Prod. 2010;73:1015-21.

10. Wagner $\mathrm{H}$. Synergy research: approaching a new generation of phytopharmaceuticals. Fitoterapia. 2011;82:34-7.

11. van Vuuren $S$, Holl D. Antimicrobial natural product research: a review from a south African perspective for the years 2009-2016. J Ethnopharmacol. 2017:208:236-52.

12. Serpeloni JM, Barcelos GRM, Mori MP, Yanagui K, Vilegas W, Varanda EA, de Syllos Colus IM. Cytotoxic and mutagenic evaluation of extracts from plant species of the Miconia genus and their influence on doxorubicin-induced mutagenicity: an in vitro analysis. Exp Toxicol Pathol. 2011;63:499-504.

13. de Oliveira RG, Mahon CPAN, Ascêncio PGM, Ascêncio SD, Balogun SO, de Oliveira Martins DT. Evaluation of anti-inflammatory activity of hydroethanolic extract of Dilodendron bipinnatum Radlk. J Ethnopharmacol. 2014;155:387-95. 
14. Fennell CW, Lindsey KL, McGaw LJ, Sparg SG, Stafford Gl, Elgorashi EE, Grace OM, van Staden J. Assessing African medicinal plants for efficacy and safety: pharmacological screening and toxicology. J. Ethnopharmacol. 2004;94:205-17.

15. Nondo RS, Moshi MJ, Erasto P, Zofou D, Njouendou AJ, Wanji S, Ngemenya MN, Kidukuli AW, Masimba PJ, Titanji VP. Evaluation of the cytotoxic activity of extracts from medicinal plants used for the treatment of malaria in Kagera and Lindi regions, Tanzania. J Appl Pharm Sci. 2015;5:007-12.

16. Kudumela RG, Masoko P. In vitro assessment of selected medicinal plants used by the Bapedi Community in South Africa for treatment of bacterial infections. J Evid Based Integr Med. 2018;23:2515690X18762736.

17. Leistner OA, editor. Seeds plants of Southern Africa: families and genera. In: Southern African Botanical Diversity Network Report No 26. Pretoria: Southern African Botanical Diversity Network; 2000.

18. Brink M. Dombeya rotundifolia (Hochst) planch. In: Louppe D, OtengAmoako AA, Brink M, editors. Plant resources of tropical Africa. Vol. 7. Totnes, England: Earthprint limited; 2008. p. 223-4.

19. Maphosa V, Masika PJ, Moyo B. Investigation of the anti-inflammatory and antinociceptive activities of Elephantorrhiza elephantina (Burch.) Skeels root extract in male rats. Afr J Biotechnol. 2009;8:7068-72.

20. Sandoval P, Choque J, Uriona P. Cartilla popular sobre las plantas utiles de los Alten*os de Mizque-Cochabamba. Cochabamba, Bolivia: FONAMA-CIBEUMSA; 1996.

21. Sacho H, Schoub BD. Current Properties on Nosocomial Infections. (Glaxo Wellcome sponsored pamphlet). Natal, South Africa: The Natal Witness Printing and Publishing Company; 1993.

22. National Committee for Clinical Laboratory Standards. Performance Standards for Antimicrobial Disk Susceptibility Tests. 4th ed. Villanora: Approved Standard NCCLS Document M2-A4; 1992.

23. Eloff JN. A sensitive and quick microplate method to determine the minimal inhibitory concentration of plant extracts for bacteria. Planta Med. 1998;64:711-3.

24. Mabona U, Viljoen A, Shikanga E, Marston A, van Vuuren S. Antimicrobial activity of southern African medicinal plants with dermatological relevance: from an ethnopharmacological screening approach, to combination studies and the isolation of a bioactive compound. J Ethnopharmacol. 2013;148:45-55.

25. van Vuuren SF, Viljoen AM. In vitro evidence of phyto-synergy for plant part combinations of Croton gratissimus (Euphorbiaceae) used in African traditional healing. JEthnopharmacol. 2008;119:700-4.

26. Sekhar S, Sampath-Kumara KK, Niranjana SR, Prakash HS. Attenuation of reactive oxygen/nitrogen species with suppression of inducible nitric oxide synthase expression in RAW 264.7 macrophages by bark extract of Buchanania lanzan. Pharmacogn Mag. 2015;11:283-91.

27. Mosmann T. Rapid colorimetric assay for cellular growth and survival: application to proliferation and cytotoxicity assays. J Immunol Methods. 1983:65:55-63.

28. Itharat A, Houghton PJ, Eno-Amooquaye E, Burke PJ, Sampson JH, Raman A. In vitro cytotoxic activity of Thai medicinal plants used traditionally to treat cancer. J Ethnopharmacol. 2004;90:33-8.

29. Ríos JL, Recio MC. Medicinal plants and antimicrobial activity. J Ethnopharmacol. 2005;100:80-4.

30. Masoko P, Gololo SS, Mokgotho MP, Eloff JN, Howard RL, Mampuru LJ. Evaluation of the antioxidant, antibacterial and antiproliferatory activities of the acetone extracts of the roots of Senna italica (Fabaceae). Afri J Trad Compl Altern Med. 2010;7(2):138-48.

31. Mpofu S, Ndinteh DT, van Vuuren S, Olivier D, Krause R. Interactive efficacies of Elephantorrhiza elephantina and Pentanisia prunelloides extracts andisolated compounds against gastrointestinal bacteria. S Afr J Bot. 2014; 94:224-30

32. Aaku E, Dharani SP, Majinda RRT, Motswaiedi MS. Chemical and antimicrobial studies on Elephantorrhiza elephantina. Fitoterapia. 1998;69:464-5.

33. Reid KA, Jäger AK, van Staden J. Pharmacological and phytochemical properties of Dombeya rotundifolia. S Afr J Bot. 2001;67:349-53.

34. Mathabe MC, Nikolova RV, Lall N, Nyazema NZ. Antibacterial activities of medicinal plants used for the treatment of diarrhoea in Limpopo Province, South Africa. J Ethnopharmacol. 2006;105:286-93.

35. Mupfure A, GHM M, Imbayarwo-Chikosi VE, Nyamushamba GB, Marandure T, Masama E. Potential use of Schkuhria Pinnata in the control of Mastitis pathogens. Int J Innov Res Dev. 2014;3:ISSN 2278-0211.
36. Wambugu SN, Mathiu PM, Gakuya DW, Kanui TI, Kabasa JD, Kiama SG. Medicinal plants used in the management of chronic joint pains in Machakos and Makueni counties, Kenya. J Ethnopharmacol. 2011;137: 945-55.

37. Ames BN, Shigenaga MK, Hagen TM. Oxidants, antioxidants, and the degenerative diseases of aging. Proc Natl Acad Sci U S A. 1993;90:7915-22. [PMC free article] [PubMed]

38. Luseba D, Elgorashi EE, Ntloedibe DT, van Staden J. Antibacterial, antiinflammatory and mutagenic effects of some medicinal plants used in South Africa for the treatment of wounds and retained placenta in livestock. S Afri J of Bot. 2007:73:378-83.

39. Fotakis $\mathrm{G}$, Timbrell JA. In vitro cytotoxicity assays: comparison of $\mathrm{LDH}$, neutral red, MTT, and protein assay in hepatoma cell lines following exposure to cadmium chloride. Toxicol Lett. 2006;160:171-7.

40. Deutschländer MS, van de Venter M, Roux S, Louw J, Lall N. Hypoglycaemic activity of four plant extracts traditionally used in South Africa for diabetes. J Ethnopharmacol. 2009;124:619-24.

41. McGaw LJ, van der Merwe D, Eloff JN. In vitro anthelmintic, antibacterial and cytotoxic effects of extracts from plants used in south African ethnoveterinary medicine. Vet J. 2007;173:366-72.

42. Caamal-Fuentes E, Torres-Tapia LW, Simá-Polanco P, Peraza-Sánchez SR, Moo-Puc R. Screening of plants used in Mayan traditional medicine to treat cancer-like symptoms. J Ethnopharmacol. 2011;135:719-24.

43. Nchu F, Githiori JB, McGaw $\sqcup$, Eloff JN. Anthelmintic and cytotoxic activities of extracts of Markhamia obtusifolia Sprague (Bignoniaceae). Vet Parasitol. 2011;183:184-8

\section{Ready to submit your research? Choose BMC and benefit from:}

- fast, convenient online submission

- thorough peer review by experienced researchers in your field

- rapid publication on acceptance

- support for research data, including large and complex data types

- gold Open Access which fosters wider collaboration and increased citations

- maximum visibility for your research: over $100 \mathrm{M}$ website views per year

At BMC, research is always in progress.

Learn more biomedcentral.com/submissions 